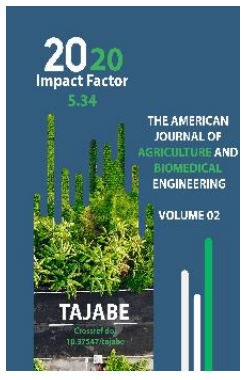

Copyright: Original content from this work may be used under the terms of the creative commons attributes 4.0 licence.

\section{Intensive Technology Before Seeding Treatment And Agrophysical Soil Properties}

\author{
Mamatojiev Sharip Ikromovich \\ Candidate Of Agricultural Sciences, Associate Professor Of The Department "Technology Of \\ Storage And Primary Processing Of Agricultural Products", Fergana Polytechnic Institute, \\ Fergana, Uzbekistan \\ Xadyatullayeva Nafisa Abdusamadova \\ Assistant, Department Of "Technology Of Storage And Primary Processing Of Agricultural \\ Products", Fergana Polytechnic Institute, Fergana, Uzbekistan
}

\title{
ABSTRACT
}

In the complex of agro-technical measures for the cultivation of cotton and obtaining high yields based on technical progress, the main and pre-sowing soil cultivation, biological characteristics of the variety, the timing and methods of sowing, rational water, nutritional, agrophysical soil regimes, optimal plant density and other agro-technical methods are important. Depending on the climatic, soil and hydrogeological conditions of the region. Before seeding, tillage is one of the most energyintensive operations in agriculture. It requires a large amount of equipment, oil products, labour resources and time. Also, under conditions of intensification of agriculture, cultivation, along with a positive effect, can have a negative effect on the agrophysical properties of the soil if it is carried out incorrectly.

\section{KEYWORDS}

Application of fertilizers, coating, current layout, cutting furrows, minimization of soil tillage, repeated tillage, spare watering, spring double chiselling by $12-14 \mathrm{~cm}$, two times harrowing, two-tier ash ploughing by $40 \mathrm{~cm}$, washing.

\section{INTRODUCTION}

The use of heavy tractors and tools compacts the arable and even sub-arable layers of the soil. Frequent loosening, activating biological processes and mineralization of organic matter, lead to significant losses of unused nitrogen by the plant and a decrease in soil humus, as well as to the development of erosion. Therefore, the development of more 
economic technologies before sowing tillage, providing a significant reduction in energy and labour costs, eliminating the negative impact on the agrophysical properties and soil fertility is a prerequisite for modern agriculture [1-3]. In this regard, it became necessary to develop techniques aimed at minimizing tillage.

\section{MATERIALS AND METHODS}

The study of the possibility of reducing the number of tillage treatments of the soil for cotton and their effect on the growth, development, some agrophysical properties of the soil, as well as on the value of the yield were carried out by us in 2018-2019 in the farm named after Nozimakhon Makhmur of the Altyaryk district of the Fergana region. Determination of the water-physical properties and nutrient regime of the soil was carried out by the method of the "Soyuz NIKHI", crumbling of the soil after before sowing treatment was determined at three points of each option I and III repetitions. The samples were sieved through a set of sieves with a hole diameter of 100, 50, 10, 0.5, 0.25 $\mathrm{mm}$. The bulk density was determined using a cylinder with a capacity of $502.4 \mathrm{~cm} 2$, soil moisture by the thermostat method for 6 hours, at 1050, the content of nitrates in the soil was determined by the Granvald-Lyazh method, humus by the Tyurin method, total nitrogen - by Kjeldahl, gross phosphorus according to Lorentz and potassium according to the method of P.V. Protasova. Crop accounting - by the plot. Mathematical processing of crop data was performed by the method of analysis of variance according to V.N. Peregudov [4]. The agricultural technique of cultivating cotton on the experimental plot during the growing season was generally accepted for this zone. The experiment scheme is shown in Table 1. For 2 years during the growing season of cotton, the following agrophysical studies were carried out experimentally:

a) crumbling of the soil after before sowing treatment before sowing cotton at three points of each option I and III repetitions. The samples were sieved through a set of sieves with a hole diameter of 100, 50, 10, $0.25 \mathrm{~mm}$;

b) bulk density of soil on samples taken with a cylinder at three points on all variants I and III repetitions after sowing and at the end of the growing season[5-8].

Table 1. Experience scheme

\begin{tabular}{|c|c|c|c|c|}
\hline 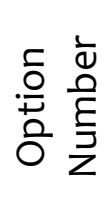 & The 2018 year & 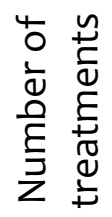 & The 2019 year & 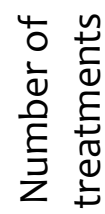 \\
\hline 1 & $\begin{array}{c}\text { Fertilization + two-tier autumn } \\
\text { plowing by } 40 \mathrm{~cm}+\text { current } \\
\text { layout + handicraft plow + } \\
\text { washing + spreading plough + } \\
\text { spring two-fold chiseling by 12- } \\
14 \mathrm{~cm}+\text { two-fold harrowing + } \\
\text { chalking (control) }\end{array}$ & 10 & $\begin{array}{l}\text { Rooting + fertilization + } 40 \\
\text { cm two-tiered plowing + } \\
\text { current layout + two-fold } \\
\text { spring chisel-growing + } \\
\text { furrowing + emergency } \\
\text { watering + two-fold } \\
\text { harrowing (control) }\end{array}$ & 9 \\
\hline
\end{tabular}




\begin{tabular}{|c|c|c|c|c|}
\hline 2 & $\begin{array}{c}\text { Fertilization }+40 \mathrm{~cm} \text { two-tiered } \\
\text { autumn plowing + current } \\
\text { layout + handcraft plow + } \\
\text { rinsing + spreading plow + } \\
\text { furrowing + spare watering + } \\
\text { harrowing }\end{array}$ & 7 & $\begin{array}{c}\text { Rooting + fertilization + } \\
\text { plowing by } 20-22 \mathrm{~cm}+ \\
\text { furrowing + spare watering } \\
\text { + harrowing. }\end{array}$ & 5 \\
\hline 3 & $\begin{array}{c}\text { Fertilization }+40 \mathrm{~cm} \text { two-tiered } \\
\text { autumn plowing + current } \\
\text { layout + furrowing + spare } \\
\text { watering + harrowing }\end{array}$ & 5 & $\begin{array}{c}\text { Rooting + fertilization + } \\
\text { two-tier autumn plowing by } \\
40 \mathrm{~cm}+\text { current layout + } \\
\text { handicraft plow + washing + } \\
\text { spreading plow + cutting } \\
\text { furrows + spare watering + } \\
\text { harrowing }\end{array}$ & 8 \\
\hline 4 & $\begin{array}{c}\text { Fertilization }+40 \mathrm{~cm} \text { two-tiered } \\
\text { plowing + current layout + } \\
\text { furrowing + emergency } \\
\text { watering + harrowing }\end{array}$ & 6 & $\begin{array}{l}\text { Rooting + cutting of } \\
\text { furrows + autumn washing } \\
\text { along furrows + spare } \\
\text { watering in spring along old } \\
\text { furrows with a rate of 500- } \\
600 \mathrm{~m} 3 / \text { ha + fertilization + } \\
\text { harrowing }\end{array}$ & 4 \\
\hline 5 & $\begin{array}{l}\text { Fertilization }+40 \mathrm{~cm} \text { two-tiered } \\
\text { autumn plowing + current } \\
\text { layout + chisel harrowing + } \\
\text { furrowing + spare furrow } \\
\text { irrigation + harrowing }\end{array}$ & 6 & $\begin{array}{l}\text { Rooting + fertilization + } \\
\text { plowing } 20 \mathrm{~cm} \text { with } \\
\text { loosening } 20 \mathrm{~cm}+\text { cutting } \\
\text { furrows + spare watering + } \\
\text { harrowing }\end{array}$ & 5 \\
\hline
\end{tabular}

The quality of pre-sowing treatments is determined by the degree of soil crumbling $[9,10]$. It is known that pre-sowing cultivation tools must provide good crumbling of the soil throughout the cultivated layer. If carried out correctly before sowing, the largest amount of favourable, agronomic valuable fractions of $10-0.25 \mathrm{~mm}$ in size is formed.

\section{RESULTS AND DISCUSSION}

The results of our research showed that crumbling of the soil depends on the technology and the amount before sowing tillage of soil for cotton (Table 2). 
The American Journal of Agriculture and Boimedical Engineering

(ISSN - 2689-1018)

Published: November 30, 2020 | Pages: 47-52

Doi: https://doi.org/10.37547/tajabe/Volume02Issue11-09

Table 2. Soil crumbling, depending on technology and multiplicity before sowing treatment for cotton

\begin{tabular}{|c|c|c|c|c|c|c|c|c|}
\hline \multirow{3}{*}{ 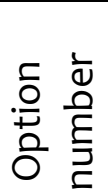 } & \multicolumn{4}{|c|}{ The 2018 year } & \multicolumn{4}{|c|}{ The 2019 year } \\
\hline & \multicolumn{8}{|c|}{ Fraction size, $\mathrm{mm}$} \\
\hline & $100-50$ & $50-10$ & $10-0,25$ & 0,25 & $100-50$ & $50-10$ & $10-0,25$ & 0,25 \\
\hline 1 & 14,7 & 19,2 & 50,5 & 15,6 & 15,1 & 18,3 & 50,0 & 16,6 \\
\hline 2 & 15,2 & 17,0 & 56,6 & 12,2 & 16,9 & 18,1 & 57,5 & 7,5 \\
\hline 3 & 15,6 & 17,3 & 58,1 & 9,0 & 16,3 & 17,8 & 56,6 & 9,3 \\
\hline 4 & 15,5 & 17,0 & 58,3 & 9,2 & 15,4 & 18,0 & 57,0 & 9,6 \\
\hline 5 & 15,7 & 17,5 & 56,2 & 10,6 & 15,5 & 17,1 & 57,7 & 9,7 \\
\hline
\end{tabular}

When cultivating cotton in the first year (2018), there were more agronomic valuable fractions of $10-0.25 \mathrm{~mm}$ in var. 2-5 with a minimum before sowing treatment, consisting of 5-7 operations - $56.2-58.3 \%$, versus $50.5 \%$ in control option 1 with 10 operations. 3-5 additional treatments - chisel-harrowing, double harrowing and one levelling the ground, carried out in the control variant, negatively affected the crumbling of the soil. Under the influence of multiple treatments before sowing, the number of dusty particles less than $0.25 \mathrm{~mm}$ in size, compared with the minimum treatment, increased 0.8-1.8 times.

In 2019, when cultivating cotton in the second year, the number of agronomic valuable aggregates measuring 10-0.25 mm per var. 2-5 ranged from 57.0 to $57.7 \%$ versus $50.0 \%$ in the control. Thus, there were more agronomic valuable soil fractions with a size of 10-0.25 $\mathrm{mm}$ in the minimum variants before sowing.

The number of dusty soil particles $>0.25 \mathrm{~mm}$ under the influence of multiple tillages before sowing increases in comparison with minimal tillage by one or more times.

Consequently, the use of multiple treatments before sowing within two years worsened the structure of the soil and led to its strong spraying. In the conditions of irrigated agriculture, the most important indicator of the water-physical properties of the arable layer, which determines its effective fertility, is the density of the soil composition. It has been established that the water-physical properties of soils, the course of biological processes, the use of applied fertilizers, the growth, development and yield of cotton find the most favourable expression in those cases when the density of the soil is within optimal limits.

The bulk density was determined after sowing and at the end of the cotton-growing season before the cotton harvest. Given in table. 3 data show that the value of the volumetric mass of the soil largely depends on the depth of the main tillage, after which the technologists of the pre-sowing preparation cultivated cotton.

So, in 2018 in var. 1 at 10 before sowing soil treatments for cotton, the bulk soil mass in the $0-40 \mathrm{~cm}$ layer after sowing was $1.32 \mathrm{~g} / \mathrm{cm} 3$ in the control, while in var. 2-5 with minimal processing - 5-7 operations -1.24-1.27 g/cm3, at the end of the growing season -1.37 and 1.35$1.37 \mathrm{~g} / \mathrm{cm}_{3}$, respectively (Table 3 ).

In 2019, in the cultivation of cotton, a slight increase in the volumetric mass of the soil in this layer was noted, and it was 1.31 after sowing cotton in the control, with a minimum before sowing in var. 2-5-1.26-1.30 $\mathrm{g} / \mathrm{cm} 3$, at the end of the growing season - respectively 1.38 and $1.36-1.40 \mathrm{~g} / \mathrm{cm} 3$. 
The American Journal of Agriculture and Boimedical Engineering

(ISSN - 2689-1018)

Published: November 30, 2020 | Pages: 47-52

Doi: https://doi.org/10.37547/tajabe/Volume02Issue11-09

Table 3. Influence of the minimum before sowing treatment on the change in the bulk soil mass during cotton cultivation, $\mathrm{g} / \mathrm{cm}^{3}$

\begin{tabular}{|c|c|c|c|c|c|c|c|c|c|c|}
\hline \multirow{3}{*}{ 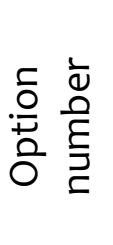 } & \multicolumn{5}{|c|}{ The 2018 year } & \multicolumn{5}{|c|}{ The 2019 year } \\
\hline & \multicolumn{10}{|c|}{ Soil layer, cm } \\
\hline & $\frac{0}{o}$ & $\begin{array}{l}\stackrel{ }{N} \\
\text { ó }\end{array}$ & $\begin{array}{l}\stackrel{一}{\eta ்} \\
\grave{N}\end{array}$ & $\begin{array}{l}\text { o } \\
\text { ț } \\
\text { ò }\end{array}$ & $\begin{array}{l}\text { o } \\
\text { o }\end{array}$ & $\frac{0}{5}$ & $\begin{array}{l}\stackrel{0}{N} \\
\text { ó }\end{array}$ & $\begin{array}{l}\stackrel{o}{n} \\
\text { ò }\end{array}$ & \begin{tabular}{l}
0 \\
\multirow{1}{1}{} \\
o \\
m
\end{tabular} & \begin{tabular}{l} 
o \\
\multirow{1}{*}{} \\
ć
\end{tabular} \\
\hline \multicolumn{11}{|c|}{ After planting cotton } \\
\hline 1 & 1,20 & 1,28 & 1,36 & 1,44 & 1,32 & 1,20 & 1,32 & 1,36 & 1,37 & 1,31 \\
\hline 2 & 1,16 & 1,23 & 1,28 & 1,37 & 1,26 & 1,12 & 1,24 & 1,41 & 1,41 & 1,29 \\
\hline 3 & 1,14 & 1,22 & 1.27 & 1,35 & 1,24 & 1,15 & 1,26 & 1,30 & 1,32 & 1,27 \\
\hline 4 & 1,14 & 1,22 & 1,27 & 1,36 & 1,25 & 1,15 & 1,26 & 1,39 & 1,40 & 1,30 \\
\hline 5 & 1,16 & 1,23 & 1,28 & 1,37 & 1,26 & 1,14 & 1,25 & 1,40 & 1,40 & 1,30 \\
\hline \multicolumn{11}{|c|}{ At the end of the growing season, before harvesting cotton } \\
\hline 1 & 1,24 & 1,37 & 1,42 & 1,47 & 1,37 & 1,22 & 1,42 & 1,44 & 1,46 & 1,43 \\
\hline 2 & 1,23 & 1,35 & 1,41 & 1,45 & 1,36 & 1,21 & 1,42 & 1,47 & 1,49 & 1,40 \\
\hline 3 & 1,22 & 1,36 & 1,40 & 1,43 & 1,35 & 1,20 & 1,40 & 1,42 & 1,44 & 1,37 \\
\hline 4 & 1,22 & 1,36 & 1,40 & 1,43 & 1,35 & 1,21 & 1,40 & 1,41 & 1,43 & 1,36 \\
\hline 5 & 1,24 & 1,37 & 1,42 & 1,45 & 1,37 & 1,20 & 1,41 & 1,42 & 1,45 & 1,37 \\
\hline
\end{tabular}

From table 3 it is seen that in the first year of cotton cultivation in the options minimal to seed processing, bulk density of soil after sowing of cotton in the layer of $0-40 \mathrm{~cm}$ was equal to $1,24-1,27 \mathrm{~g} / \mathrm{cm} 3$ and in case of repeated processing in the control variant of $1.32 \mathrm{~g} / \mathrm{cm} 3$. by the end of the growing season in all embodiments, the soil was noticeably compacted, but significant various options with a different number of treatments are not available. When cotton was cultivated in the second year, the looser composition of the soil was preserved in the variants of minimal pre-sowing treatment, and in var. 1, where multiple pre-sowing treatments were carried out, some soil compaction was noted.

Consequently, looser soil composition is created and maintained in minimal treatment options. After sowing, the volume mass of soil in a layer of $0-40 \mathrm{~cm}$ in var. 1 with repeated processing was $1.32 \mathrm{~g} / \mathrm{cm} 3$ in 2018 to $2019-1.31$ $\mathrm{g} / \mathrm{cm} 3$, according to options 2-5 of minimal processing, it varied in the first year 1.24-1.27, in the second year - 1.26-1.30 $\mathrm{g} / \mathrm{cm}_{3}$, respectively.

Thus, the generalization and analysis of the results of studies of the volume mass of the soil in our field experiments in 2018-2019 allow us to conclude that an increase in the number of passes of tillage units during pre-sowing treatments of the soil for cotton causes its compaction and thereby worsens the waterphysical properties.

\section{CONCLUSION}

The development of methods of minimization and technology before sowing tillage for sowing cotton after ploughing in the conditions of meadow, saz soils of the Fergana Valley will make it possible to draw the following conclusions: 
1.

2.

\section{REFERENCES}

1. Mamatozhiev, Sh. I., \& Usarkulova, M. M. (2020). Determination of the procedure, composition and methodology for the wheat wetting process. Actual science, (1), 18-21.

2. Mamatozhiev, Sh. I. (2019). Minimum presowing tillage after plowing alfalfa with intensive cotton cultivation technology. Actual science, (11), 68-73.

3. Mamatozhiev Sharip Ikromovich, and Usarkulova Mohigul Mirkhomidzhon Kizi. "The influence of changes in the physical and chemical properties of grain depending on moisture on the uniform. distribution of the load over the surface of the crushing shaft" Problems of modern science and education, no. 4-2 (149), 2020, pp. 5-8.

4. Peregudov, V.N. (1978). Planning of multifactorial field experiments with fertilizers and mathematical processing of their results. $M$.: ear, 184 .

5. Mamatozhiev, Sh. I., Usarkulova, M. M., \& Dadazhonov, Z.Z. (2020). Determination of changes in grain friction angle depending on moisture content. Actual science, (1), 2224.

6. Mamatozhiev, Sh. I. (2019). Intensive technology of minimum pre-sowing tillage for cotton after plowing alfalfa. Actual science, (11), 63-67.

7. Mamatozhiev, Sh. I. (1990). Techniques for minimizing pre-sowing soil cultivation and their effect on the fertility and productivity of cotton in the conditions of meadow saz soils of the Fergana Valley, (Doctoral dissertation, All-Russian Research Institute of Cotton Growing).

8. Nazirova, R. M., Tadzhiev, S. M., Mirsalimova, S. R., \& Akramov, Sh. Sh. (2018). Intensive technology for obtaining PK fertilizer. Modern Research and Development, (3), 415-418.

9. Abdurakhmonov, S. Zh., Akramov, Sh. Sh., \& Bakhtiyorova, D.F. (2018). Regulation of the fruiting of cotton by removing some of the newly formed buds. Actual science, (11), 18-21.

10. Khasanov, A., Akramov, Sh., Abdurakhmonov, S., \& Kamolov, Z. (2018). Development of technology for obtaining early vegetables without the use of artificial heating. Modern Research and Development, 1 (4), 542-543.

11. Usarkulova, M., \& Mamatozhiev, Sh. (2020). The inflow of changes in the structural and mechanical power of grain is fallen from the ground to the level of growth on the surface of the crushing shaft. $\Lambda$ 'OГO $\Sigma$. ONLINE. 